\title{
Optimalisasi Sistem Informasi Penggajian dan Perhitungan Pajak Penghasilan (PPh) Pada PT.Gramaselindo Utama
}

\author{
Eduard Hotman Purba ${ }^{1}$, Giandari Maulani*2 ${ }^{2}$ Intan Fauziah ${ }^{3}$ \\ 1,2,3 Program Studi Sistem Informasi Universitas Raharja \\ Email: ${ }^{1}$ eduard@ raharja.info, ${ }^{2}$ giandari @ raharja.info, ${ }^{3}$ intan.fauziah@ @raharja.info
}

\begin{abstract}
Abstrak
Sumber daya manusia merupakan salah satu sumber daya (resources) yang penting dalam perusahaan sebagai tenaga penggerak. Sumber daya manusia yang dalam hal ini adalah karyawan, perlu untuk diperhatikan dan perusahaan memiliki kewajiban memberikan imbalan atas kerja keras, waktu, tenaga dan pemikiran dari karyawan tersebut, berupa gaji, tunjangantunjangan dan bonus yang sesuai dan tepat waktu. Hal ini dimaksudkan untuk menunjukkan niat baik perusahaan dan meningkatkan semangat kerja karyawan agar tetap produktif di dalam mengerjakan tugas-tugas hariannya. Permasalahan terjadi saat pengolahan penggajian, termasuk didalamnya penghitungan pajak penghasilan (Pph) khusus pasal 21 untuk karyawan pada PT.Gramaselindo Utama yang saat itu masih menggunakan sistem manual, sehingga menyebabkan proses penggajian sering terlambat dan kurang efektif. Perusahaan ini membutuhkan suatu sistem informasi yang cepat dan akurat sehingga proses kerja bagian personalia dan keuangan menjadi lebih efektif. Solusi untuk masalah tersebut yaitu diperlukannya optimalisasi Sistem Informasi penggajian dan perhitungan Pajak Penghasilan (Pph) pasal 21 dengan sistem informasi yang berbasis Website dan memudahkan pengguna. Metode penelitian ini menggunakan metode observasi, metode wawancara, metode pustaka dan metode analisa SWOT. Hasil akhir dari penelitian ini berupa Website perhitungan Penggajian dan Pajak Penghasilan (Pph) untuk PT.Gramaselindo Utama.
\end{abstract}

Kata kunci : Sistem Informasi, Penggajian, Pajak Penghasilan (Pph) Pasal 21.

\begin{abstract}
Human resources are one of the important resources in the company as a driving force. Human resources, which in this case are employees, need to be considered and the company has the obligation to provide rewards for the hard work, time, energy and thought of the employee, in the form of salaries, benefits and bonuses that are appropriate and timely. This is intended to show the good intentions of the company and improve employee morale in order to remain productive in carrying out their daily tasks. Problems occur when processing payroll, including the calculation of special income tax (Pph) article 21 for employees at PT. Graselindo Utama, who at that time were still using the manual system, so that the payroll process was often late and ineffective. This company needs an information system that is fast and accurate so that the work processes of personnel and finance become more effective. The solution to this problem is the need for optimization of payroll information systems and the calculation of income tax (Pph) article 21 with a website-based information system and makes it easier for users. This research method uses the method of observation, interview methods, library methods and SWOT analysis methods. The final results of this study are in the form of a Payroll and Income Tax (Pph) Website calculation for PT.Gramaselindo Utama.
\end{abstract}

Keywords: Information System, Payroll, Income Tax (Pph) Article 21. 


\section{Pendahuluan}

Komputer menjadi bagian yang tidak terpisahkan dari kehidupan manusia sekarang ini, komputer dapat membantu pekerjaan manusia dengan efektif dan efisien. Selain itu komputer dapat menghasilkan nilai informasi yang akurat. Dengan banyaknya kemudahan yang dapat diperoleh dengan menggunakan sistem komputerisasi tersebut, maka tidak sedikit perusahaan yang telah menerapkan sistem komputerisasi. Sumber daya manusia merupakan salah satu sumber daya (resources) yang penting dalam perusahaan sebagai tenaga penggerak. Perusahaan memiliki kewajiban memberikan imbalan atas kerja keras, waktu dan pemikiran dari karyawan dengan berupa gaji, tunjangan, bonus yang sesuai dan tepat waktu. Hal ini dimaksudkan untuk menunjukkan loyalitas dari perusahaan dan meningkatkan semangat karyawan perusahaan untuk tetap produktif dalam mengerjakan tugas-tugasnya. Ketelitian dalam menghitung gaji yang akan dibayarkan merupakan hal yang sangat penting. Bila sering terjadi kesalahan dalam penghitungan gaji tentu akan menimbulkan masalah. Solusi yang terbaik dalam mengatasi hal tersebut adalah dengan menggunakan sistem komputerisasi. Karena di dalam perusahaan, proses pengolahan data dengan bantuan komputer diharapkan akan menghasilkan data yang benar, cepat dan akurat, sehingga dapat meringankan pekerjaan terutama dalam pekerjaan hitunghitungan yang kompleks dan kemungkinan kesalahan yang terjadi relatif kecil. Sistem informasi penggajian yang termasuk didalamnya penghitungan Pajak Penghasilan (Pph) karyawan pada PT.Gramaselindo Utama masih menggunakan sistem manual sehingga menyebabkan proses penggajian sering terlambat dan kurang efektif. Sehingga perusahaan PT.Gramaselindo Utama membutuhkan suatu sistem informasi penggajian sekaligus perhitungan Pajak Penghasilan (Pph) khususnya pasal 21 yang cepat dan akurat dan dapat dioptimalkan agar proses kerja bagian Personalia (HRD) dan Keuangan menjadi lebih efektif dan efisien. Perusahaan sebagai Wajib Pajak Badan memiliki kewajiban untuk menyetorkan Pajak Penghasilan (Pph) atas pekerjaan ataupun jasa, apabila perusahaan tidak melaksanakan kewajiban pemotongan pajak, maka akan dikenakan sanksi berupa denda. Maka dari itu, perusahaan membutuhkan suatu sistem informasi untuk penggajian dan perhitungan pajak penghasilan khusus pasal 21 dari penghasilan yang diberikan perusahaan kepada karyawan setiap bulannya. Adapun permasalahan-permasalahan yang dihadapi oleh PT.Gramaselindo Utama dalam sistem penggajian dan perhitungan Pajak Penghasilan (Pph) khusus pasal 21 saat ini, antara lain sebagai berikut : 1) Bagaimana sistem informasi penggajian dan perhitungan Pajak Penghasilan (Pph) khusus pasal 21 saat ini pada PT.Gramaselindo Utama?. 2) Bagaimana proses pengolahan Penggajian dan perhitungan pajak penghasilan $(\mathrm{PPh})$ pasal 21 pada PT.Gramaselindo Utama agar berjalan secara efektif dan efisien? 3) Apakah laporan penggajian dan perhitungan Pajak Penghasilan (PPh) pasal 21 pada PT.Gramaselindo Utama yang berjalan selama ini dapat dihasilkan dengan cepat dan akurat?. Permasalahan-permasalahan diatas perlu untuk dicarikan solusinya agar tidak menjadi kendala di kemudian hari yang bisa saja terjadi pada PT.Gramaselindo Utama.

Jika Anda merupakan si Pemberi Kerja yang memotong Pajak Penghasilan (PPh) Pasal 21 terdapat hal-hal yang harus Anda lakukan, yaitu : 1) Melakukan melakukan pemotongan Pajak Penghasilan (PPh) Pasal 21 sesuai dengan ketentuan tarif PPh yang berlaku; 2) Membuat bukti potong Pajak Penghasilan (PPh) Pasal 21 melalui aplikasi e-SPT PPh Pasal 21; 3) Melakukan penyetoran Pajak Penghasilan $(\mathrm{PPh})$ Pasal 21 yang telah dipotong tersebut dengan terlebih dahulu membuat kode billing (MAP-KJS 411121-100). Penyetoran dilakukan paling lambat tanggal 10 bulan berikutnya. Misalnya: pemotongan Pajak Penghasilan (PPh) Pasal 21 dilakukan pada bulan April 2019, maka penyetoran PPh-nya adalah paling lambat dilakukan pada tanggal 15 bulan Mei 2019; dan 4) melakukan pelaporan Pajak Penghasilan (PPh) Pasal 21 dengan menggunakan aplikasi e-SPT PPh melalui djponline.pajak.go.id atau ASP. Jika Anda adalah orang pribadi penerima penghasilan dari pemberi kerja yang bertindak sebagai pemotong Pajak Penghasilan (PPh) Pasal 21, Anda perlu melakukan hal-hal sebagai berikut: 1) Meminta dan mendapatkan bukti pemotongan Pajak Penghasilan (PPh) Pasal 21 (1721-A1 dan 1721-A2) atas penghasilan yang diterima dan dipotong PPh Pasal 21 secara berkala. 2) Apabila Anda 
berstatus sebagai pegawai tetap dan penerima pensiun yang Pajak Penghasilan (PPh) Pasal 21 dipotong oleh pemberi kerja maupun dana pensiun, maka Anda berhak menerima bukti pemotongan setiap awal tahun. 3) Apabila Anda berstatus sebagai penerima honorarium, bukan pegawai, dan peserta kegiatan yang penghasilannya dipotong Pajak Penghasilan $(\mathrm{PPh}) \mathrm{Pasal} 21$ oleh pemberi penghasilan, maka Anda berhak menerima bukti pemotongan Pajak Penghasilan $(\mathrm{PPh})$ Pasal 21 setelah penghasilan dibayarkan. 4) Apabila Anda menerima penghasilan dari pemberi kerja, namun Pajak Penghasilan ( $\mathrm{PPh}$ ) Pasal 21 tidak dipotong, maka penghasilan tersebut wajib diperhitungkan dan dilaporkan melalui SPT Tahunan PPh Orang Pribadi pada tahun pajak yang sama [1].

\section{TINJAUAN PUSTAKA}

\section{Definisi Sistem Informasi}

Menurut Maulani (2020), Sistem Informasi adalah kumpulan dari sub-sub sistem yang tersebar secara fisik dan non-fisik yang bergabung dan saling berkaitan satu sama lain dan saling bekerja sama secara harmonis untuk mencapai suatu sasaran/tujuan tertentu yang kemudian menghasilkan sebuah informasi yang akurat, tepat waktu dan relevan [2].

\section{Definisi Gaji}

Menurut Pramesti (2020) : Pengusaha menyusun struktur dan skala upah dengan memperhatikan golongan, jabatan, masa kerja, pendidikan dan kompetensi. Ini berarti jabatan dan upah berbanding lurus. Masih berkaitan dengan upah, Pasal 92 ayat (2) UU Ketenagakerjaan mengatakan bahwa pengusaha melakukan peninjauan upah secara berkala dengan memperhatikan kemampuan perusahaan dan produktivitas. Adapun peninjauan upah tersebut menurut penjelasan pasal ini dilakukan untuk penyesuaian harga kebutuhan hidup, prestasi kerja, perkembangan, dan kemampuan perusahaan [3]. Menurut Widyana (2020) Pengupahan dalam undang-undang ketenagakerjaan dijabarkan dalam Undang-Undang No. 13 Tahun 2003 pada bab 10 tentang Pengupahan (UU Ketenagakerjaan), upah adalah hak pekerja/buruh yang diterima dan dinyatakan dalam bentuk uang sebagai imbalan dari pengusaha atau pemberi kerja kepada pekerja/buruh yang ditetapkan dan dibayarkan menurut suatu perjanjian kerja, kesepakatan, atau peraturan perundang-undangan, termasuk tunjangan bagi pekerja/buruh dan keluarganya atas suatu pekerjaan dan/atau jasa yang telah atau akan dilakukan [4].

\section{Definisi Pajak}

Menurut sumber website resmi dari www.pajak.go.id (2020), Pajak merupakan kontribusi wajib kepada negara yang terutang oleh orang pribadi atau badan yang bersifat memaksa berdasarkan undang-undang dengan tidak mendapatkan imbalan secara langsung dan digunakan untuk keperluan negara bagi sebesar-besarnya kemakmuran rakyat [5].

\section{Definisi Penghasilan}

Menurut Undang-Undang Pajak Nomor 36 Tahun 2008 pasal 4 ayat (1) bersumber dari Kementerian Keuangan (2020) menerangkan bahwa Penghasilan adalah "Setiap tambahan kemampuan ekonomis yang diterima atau diperoleh Wajib Pajak, baik yang berasal dari Indonesia maupun dari luar Indonesia, yang dapat dipakai untuk konsumsi atau untuk menambah kekayaan Wajib Pajak yang bersangkutan, dengan nama dan dalam bentuk apapun" [6].

\section{Definisi Pajak Penghasilan (PPh)}

Definisi Pajak Penghasilan (selanjutnya disingkat $\mathrm{PPh}$ ) menurut Pasal 4 ayat (2) dari www.pajak.go.id (2020) sebagai berikut : Penghasilan di bawah ini dapat dikenai PPh Pasal 4 ayat (2) bersifat final: 1) Penghasilan berupa bunga deposito dan tabungan lainnya, bunga obligasi dan surat utang negara, dan bunga simpanan yang dibayarkan oleh koperasi kepada 
anggota koperasi orang pribadi; 2) Penghasilan berupa hadiah undian; 3) Penghasilan dari transaksi saham dan sekuritas lainnya, transaksi derivatif yang diperdagangkan di bursa, dan transaksi penjualan saham atau pengalihan penyertaan modal pada perusahaan pasangannya yang diterima oleh perusahaan modal ventura; 4) Penghasilan dari transaksi pengalihan harta berupa tanah dan/atau bangunan, usaha jasa konstruksi, usaha real estate, dan persewaan tanah dan/atau bangunan; dan 5) Penghasilan tertentu lainnya yang diatur dengan atau berdasarkan Peraturan Pemerintah. Penghasilan-penghasilan tersebut merupakan objek pajak. Berdasarkan pertimbangan-pertimbangan antara lain: 1) Perlu adanya dorongan dalam rangka perkembangan investasi dan tabungan masyarakat. 2) Kesederhanaan dalam pemungutan pajak;-berkurangnya beban administrasi baik bagi Wajib Pajak maupun Direktorat Jenderal Pajak. 3) Pemerataan dalam pengenaan pajaknya dan memperhatikan perkembangan ekonomi dan moneter, atas penghasilan-penghasilan tersebut perlu diberikan perlakuan tersendiri dalam pengenaan pajaknya. Perlakuan tersendiri dalam pengenaan pajak atas jenis penghasilan tersebut termasuk sifat, besarnya dan tata cara pelaksanaan pembayaran, pemotongan atau pemungutan diatur dengan Peraturan Pemerintah [7].

\section{Definisi PPh Pasal 21}

Pajak Penghasilan (PPh) Pasal 21 menurut sumber informasi yang berasal dari www.pajak.go.id (2020) adalah Pajak atas penghasilan berupa gaji, upah, honorarium, tunjangan, dan pembayaran lain dengan nama dan dalam bentuk apapun sehubungan dengan pekerjaan atau jabatan, jasa, dan kegiatan yang dilakukan oleh orang pribadi Subjek Pajak dalam negeri [1].

\section{Definisi Karyawan}

Menurut Sora N (2017) Secara umum yang dimaksud dengan karyawan adalah orang yang bekerja di suatu perusahaan atau lembaga dan digaji dengan uang. Atau karyawan dapat diartikan juga sebagai orang yang bertugas sebagai pekerja pada suatu perusahaan atau lembaga untuk melakukan operasional tempat kerjanya dengan balas jasa berupa uang [8].

\section{Definisi Website}

Menurut Maimunah,dkk (2020) Website adalah Kumpulan halaman-halaman yang digunakan untuk menampilkan informasi teks, gambar diam/gambar gerak, animasi, suara/gabungan dari semuanya, baik yang bersifat dinamis yang membentuk satu rangkaian bangunan yang saling terkait yang masing-masing dihubungkan dengan jaringan-jaringan [9].

\section{Metode Penelitian}

\subsection{Metode Pengumpulan Data}

Metode pengumpulan data pada penelitian ini terdiri atas: Metode Observasi, Metode Wawancara, Metode Pustaka, Metode Analisa Sistem menggunakan Metode analisis SWOT dan Metode Analisa Kebutuhan Sistem.

\subsubsection{Metode Observasi}

Metode Observasi merupakan suatu metode penelitian dengan cara melakukan pengamatan secara langsung pada objek yang diteliti terhadap data-data kepegawaian serta menganalisa sistem yang dibutuhkan untuk mengetahui unsur-unsur dari sistem tersebut. Observasi merupakan salah satu dasar fundamental dari semua metode pengumpulan data dalam penelitian kualitatif, khususnya menyangkut ilmu-ilmu sosial dan perilaku manusia. Observasi juga dipahami sebagai "andalan perusahaan etnografi", maksudnya adalah observasi merupakan proses pengamatan sistematis dari aktivitas manusia dan pengaturan fisik dimana kegiatan tersebut berlangsung secara terus menerus dari lokus aktivitas bersifat alami untuk menghasilkan fakta. Oleh karena itu observasi merupakan bagian integral dari cakupan penelitian lapangan etnografi. Observasi sebagai proses komplek, tersusun dari berbagai proses 
biologis dan psikologis melibatkan pengamatan, persepsi, dan ingatan. Observasi sebagai aktivitas mencatat suatu gejala dengan bantuan instrumen-instrumen dan merekamnya dengan tujuan ilmiah atau tujuan lain. Lebih lanjut dikatakan bahwa observasi merupakan kumpulan kesan tentang dunia sekitar berdasarkan semua kemampuan daya tangkap panca indera manusia. Observasi sebagai suatu proses melakukan pemilihan, pengubahan, pencatatan dan pengkodean serangkaian perilaku dan suasana berkenaan dengan organisme, sesuai dengan tujuan-tujuan empiris. Observasi tidak hanya meliputi prinsip kerja sederhana, melainkan memiliki karakteristik yang begitu komplek. Terdapat 7 (tujuh) karakteristik dalam kegiatan observasi dan selanjutnya menjadi proses tahapan observasi. Tahapan atau proses observasi tersebut meliputi pemilihan (selection), pengubahan (provocation), pencatatan (recording) dan pengkodean (encoding), rangkaian perilaku dan suasana (tests of behavior setting) dan untuk tujuan empiris [10].

\subsubsection{Metode Wawancara}

Metode Wawancara merupakan suatu metode untuk mendapatkan data dengan tatap muka dan tanya jawab secara lisan yang dilakukan oleh Narasumber yang berada di lingkungan perusahaan PT.Gramaselindo Utama. Penelitian ini menggunakan metode wawancara sebagai teknik yang dipilih untuk diterapkan pada kelompok eksperimen, yang dalam hal ini adalah Stakeholder dan pihak yang berwenang di Perusahaan. Karena dengan adanya metode wawancara, apa yang menjadi permasalahan, kendala dan kondisi yang sebenarnya dapat diketahui dan disimpulkan, sehingga informasi yang ingin didapat lebih lengkap dan efektif [11].

\subsubsection{Metode Studi Pustaka}

Metode pustaka merupakan suatu metode untuk mendapatkan data dengan cara mempelajari buku-buku yang berkaitan dengan penelitian dari berbagai sumber yang tertulis dan mempelajari unsur-unsur objek yang diteliti. Penelitian ini merupakan penelitian kualitatif yang bersifat studi pustaka (library research) dengan menggunakan sumber data berupa buku-buku referensi dan artikel-artikel jurnal ilmiah. Pada penelitian ini rangkaian kegiatannya berkaitan dengan pengumpulan data pustaka, membaca dan mencatat, lalu mengolah informasi yang sesuai dan diperlukan untuk menjawab rumusan masalah yang akan dipecahkan. Adapun prosedur yang dilakukan pada penelitian studi pustaka ini meliputi: 1) Menggali ide umum tentang penelitian, 2) Mencari informasi yang mendukung topik penelitian, 3) Mempertegas fokus penelitian dan mengorganisasi bahan yang sesuai, 4) Mencari dan menemukan sumber data berupa sumber pustaka utama yaitu buku dan artikelartikel jurnal ilmiah, 5) melakukan reorganisasi bahan dan catatan simpulan yang didapat dari sumber data, 6) melakukan review atas informasi yang telah dianalisis dan sesuai untuk membahas dan menjawab rumusan masalah penelitian, 7) memperkaya sumber data untuk memperkuat analisis data dan 8) menyusun hasil penelitian [12].

\subsection{Metode Analisis Sistem}

Metode Analisis Sistem pada penelitian ini terdiri dari: Analisis SWOT dan Analisis Kebutuhan Sistem, yang akan dijelaskan masing-masingnya dibawah ini.

\subsubsection{Analisis SWOT}

Berdasarkan sistem yang berjalan di PT.Gramaselindo Utama dilakukan penelitian analisis. Analisis ini digunakan untuk mencari strategi dengan menggunakan Kekuatan/Strengths, Kelemahan/Weakness, Peluang/Opportunities dan Ancaman/Threats (SWOT). Analisis SWOT merupakan penilaian menyeluruh terhadap Kekuatan (Strengths), Kelemahan (Weaknesses), Peluang (Opportunities) dan Ancaman (Threats) suatu perusahaan. SWOT digunakan untuk menilai kekuatan-kekuatan dan kelemahan-kelemahan dari sumber-sumber daya yang dimiliki perusahaan dan kesempatan-kesempatan eksternal dan tantangan-tantangan yang dihadapi. Semua organisasi memiliki kekuatan dan kelemahan dalam area fungsional bisnis, yang 
dapat digunakan sebagai dasar untuk tujuan dan penetapan strategi suatu organisasi. Jadi, analisis SWOT merupakan instrumen yang bermanfaat dalam melakukan analisis strategi, dalam konteks artikel ini ditujukan untuk menilai kualitas layanan perbankan, sehingga diharapkan mampu meminimalisasi kelemahan yang terdapat dalam suatu lembaga perbankan serta menekan dampak ancaman yang timbul dan harus dihadapi [13].

\section{PENELITIAN YANG RELEVAN}

Menurut Romi Satrio Wahono (2016) Literature review tidak hanya bermakna membaca literatur, tapi lebih ke arah evaluasi yang mendalam dan kritis tentang penelitian sebelumnya pada suatu topik. Literature review yang baik yaitu yang melakukan evaluasi terhadap kualitas dan temuan baru dari suatu paper ilmiah. Perlu dipahami bahwa yang disebut dengan literatur ilmiah dapat berupa: Paper dari Jurnal Ilmiah, Paper dari Conference (Proceedings), Sumber dari Skripsi, Tesis dan Disertasi, Sumber dari Report (Laporan) dari Organisasi yang Terpercaya serta yang berasal dari Buku-buku Textbook.[14]

Dalam upaya mengembangkan dan menyempurnakan penelitian jurnal ini, maka perlu dilakukan studi pustaka (literature review) yang merupakan salah satu penerapan metode penelitian dengan menggunakan bahan perbandingan. Literature Review dalam penelitian ini diantaranya :

1. Penelitian yang dilakukan oleh Syaiful Amarullah Isnaini dari Universitas Islam Negeri Syarif Hidayatullah yang berjudul "Aplikasi Perhitungan Pajak Penghasilan Pasal 21 dan SSP Multi Function Berbasis Website (Studi Kasus : CV.Buana Mitra Consulting)". CV.Buana Mitra Consulting adalah perusahaan jasa konsultan pajak yang menggunakan internet sebagai alat untuk mengoptimalisasi pekerjaannya. Dalam menangani kliennya yang berjumlah puluhan, terkadang mengalami kesulitan karena terbatasnya karyawan. Tujuan dari penelitian ini adalah untuk menambah fasilitas aplikasi perhitungan pajak PPh 21 badan dan SSP berbasis Web. Metode yang dilakukan adalah metode pengumpulan data, dengan observasi, wawancara dan studi pustaka [15].

2. Penelitian yang dilakukan oleh Butet Uli Artha Panjaitan dari Universitas Sanata Dharma Yogyakarta yang berjudul "Evaluasi Perhitungan Pajak Penghasilan Pasal 21 Studi Kasus Pada PT.X" Dalam menjalankan kegiatan usaha, faktor yang sangat penting dalam menentukan keberhasilan adalah Sumber Daya Manusia. Perusahaan sebagai wajib pajak badan / pemilik perusahaan memiliki kewajiban untuk melakukan pemotongan pajak PPh 21 atas penghasilan sehubungan dengan pekerjaan, jasa, atau kegiatan dengan nama dan dalam bentuk apapun yang diterima atau diperoleh wajib pajak orang pribadi dalam negeri. Tujuan dari penelitian ini adalah untuk mengetahui perhitungan pajak penghasilan Pasal 21 dalam satu tahun pajak telah mengacu pada peraturan perpajakan yang berlaku di Indonesia [16].

3. Penelitian yang dilakukan oleh Maghfirah, Hera Bugis Indina dari Universitas Hasanudin Makasar yang berjudul "Analisis Perencanaan Pajak Penghasilan (PPh) Pasal 21

Pegawai Tetap pada PT.Semen Tonasa" Penelitian ini bertujuan untuk mengetahui cara meminimalisir jumlah kewajiban pajak terutang yang harus dibayarkan dan sesuai dengan undang - undang perpajakan yang berlaku dan ingin melihat sejauh mana pengaruh perencanaan pajak atas PPh 21 yang dibayarkan oleh PT.Semen Tonasa sehingga mendapatkan laba yang optimal. Hasil yang didapatkan dari penelitian ini adalah bahwa PT.Semen Tonasa telah melakukan perencanaan pajak dengan baik karena adanya keuntungan yang didapat dengan melakukan penghematan pajak dan peningkatan laba komersial [17] 


\section{Hasil Dan Pembahasan}

Tabel 1. Analisis SWOT

\begin{tabular}{|c|c|}
\hline Strength & Weakness (Kelemahan) \\
\hline $\begin{array}{l}\text { 1. Tidak memerlukan spesifikasi komputer } \\
\text { yang tinggi untuk dapat menggunakan } \\
\text { aplikasi berbasis Website untuk Penggajian } \\
\text { dan perhitungan Pajak Penghasilan (Pph) } \\
\text { pasal } 21 \text { untuk setiap karyawan } \\
\text { PT.Gramaselindo Utama. } \\
\text { 2. Dapat menjalankan aplikasi berbasis } \\
\text { Website dimanapun kapanpun tanpa harus } \\
\text { melakukan penginstalan, serta dapat } \\
\text { dijalankan pada sistem operasi apapun. } \\
\text { 3. Pengelolaan sistem informasi penggajian } \\
\text { dan perhitungan Pajak Penghasilan (Pph) } \\
\text { dengan menggunakan aplikasi Website } \\
\text { dapat membantu manajemen meningkatkan } \\
\text { kinerja kerja HRD dan Accounting Staff. }\end{array}$ & $\begin{array}{l}\text { 1. Jika aplikasi Website sistem informasi } \\
\text { penggajian dan perhitungan Pajak } \\
\text { Penghasilan (Pph) pasal } 21 \text { ini mengalami } \\
\text { masalah / Error maka dapat mengganggu } \\
\text { jalannya aktivitas pajak beserta hasil } \\
\text { perhitungannya. } \\
\text { 2. Karyawan yang ingin melihat rincian } \\
\text { penggajian dan hasil perhitungan Pajak } \\
\text { Penghasilan (Pph) harus memiliki izin } \\
\text { mengakses Website ini, karena } \\
\text { bagaimanapun juga data penggajian dan } \\
\text { perhitungan Pajak Penghasilan (Pph) } \\
\text { pasal } 21 \text { ini masih bersifat Privacy atau } \\
\text { Confidential. }\end{array}$ \\
\hline Oppor & \\
\hline $\begin{array}{l}\text { 1. Karyawan memiliki kesempatan melihat } \\
\text { detail/rincian penggajian dan perhitungan } \\
\text { Pajak Penghasilan (Pph) yang dipotong oleh } \\
\text { perusahaan, dalam hal ini pemotongan Pph } \\
\text { setiap karyawan secara transparan oleh } \\
\text { PT.Gramaselindo Utama. }\end{array}$ & $\begin{array}{l}\text { 1. Untuk Data-data penggajian dan } \\
\text { perhitungan Pajak Penghasilan (Pph) } \\
\text { pasal } 21 \text { yang terdapat pada Website, jika } \\
\text { tidak hati-hati dan sistem keamanannya } \\
\text { kurang, maka data-datanya dapat diambil, } \\
\text { dirusak atau disalahgunakan oleh hacker } \\
\text { jahat. }\end{array}$ \\
\hline
\end{tabular}

\subsection{Alternatif Solusi dari Identifikasi Masalah}

Berdasarkan identifikasi masalah PT.Gramaselindo Utama di atas, maka diajukanlah alternatif solusi dari permasalahan tersebut, antara lain sebagai berikut : 1) Membangun suatu aplikasi sistem informasi yang berbasis Website, karena sebuah aplikasi yang dibangun berbasiskan Website ini dapat memudahkan User / HRD/ Accounting Staff dalam melakukan pengolahan penggajian dan perhitungan Pajak Penghasilan (Pph) pasal 21. 2) Aplikasi sistem informasi Website ini merupakan sebuah aplikasi berbasis Visual yang memiliki tampilan yang menarik dan sudah familiar di kalangan masyarakat sekarang ini, sehingga mudah untuk dioperasikan/digunakan. Aplikasi yang dirancang merupakan solusi yang tepat untuk mengatasi permasalahan yang ada pada sistem yang berjalan. Sistem informasi berbasis Website ini dibuat dengan menggunakan bahasa pemrograman $A S P$, MySQL untuk mengelola database-nya dan menggunakan Xampp sebagai aplikasi penghubung yang menyambungkan $A S P$ dan $M y S Q L$ serta aplikasi Adobe Dreamweaver untuk membuat desain dan Notepad++ sebagai editor.

\subsection{Analisa Prosedur Sistem yang Berjalan}

Pada sistem yang ada saat ini berdasarkan dari prosedur sistem yang berjalan di PT.Gramaselindo Utama, maka dibuatlah gambaran alur kerjanya dengan menggunakan Unified Modeling Language (UML) yang antara lain sebagai berikut : 


\subsubsection{Use Case Diagram}

Use Case diagram merupakan salah satu bentuk diagram yang mudah dibaca dan dimengerti. Use case diagram menggambarkan aktivitas-aktivitas yang terjadi dalam sistem yang berjalan yang ada di PT.Gramaselindo Utama. Berikut Use Case Diagram-nya :

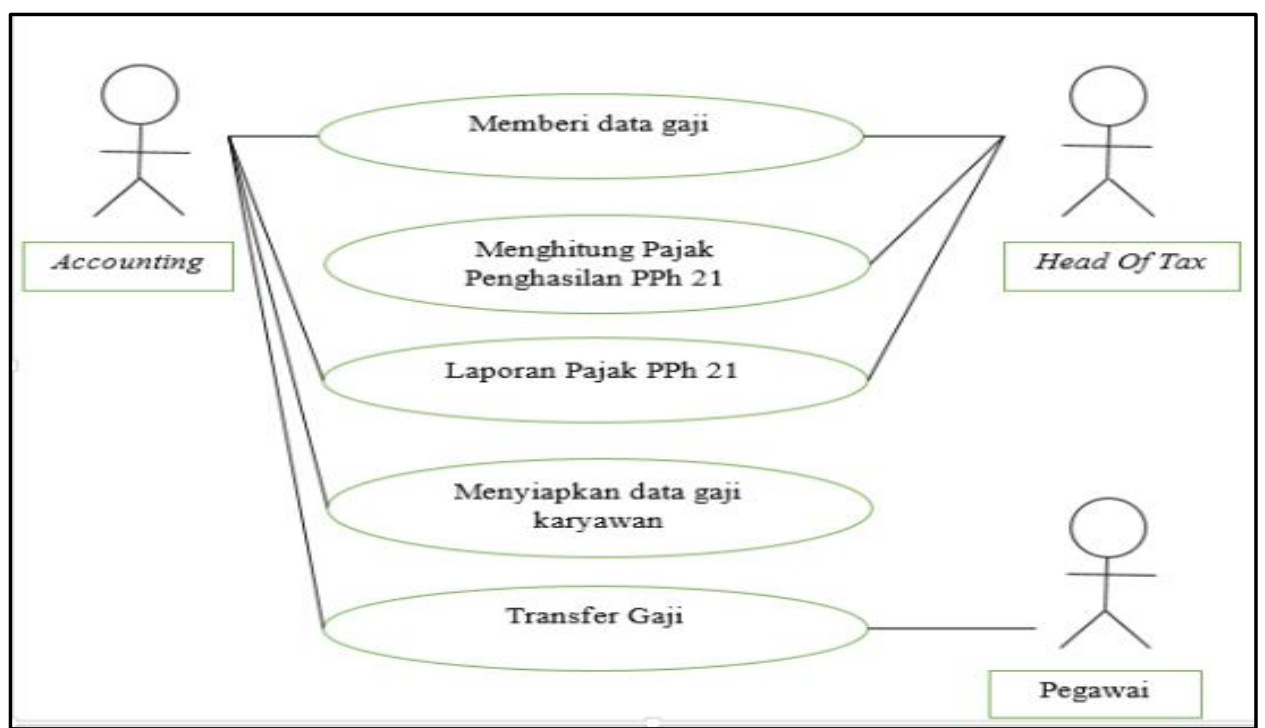

Gambar 1. Use Case Diagram Sistem yang Berjalan

\subsubsection{Activity Diagram}

Berdasarkan dari use case diagram diatas dapat kita gambarkan activity diagram dari aktivitas para aktor-aktor yang ada pada sistem yang berjalan di PT.Gramaselindo Utama sebagai berikut:

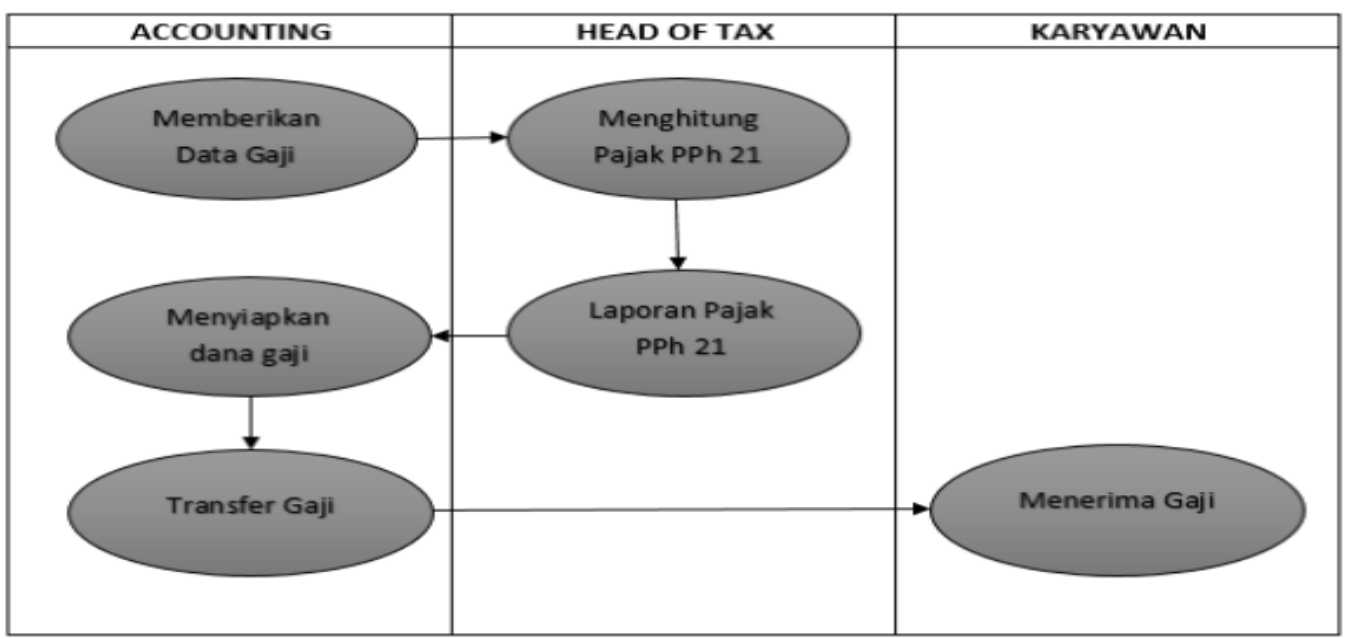

Gambar 2. Activity Diagram Sistem yang Berjalan 


\subsection{Rancangan Sistem}

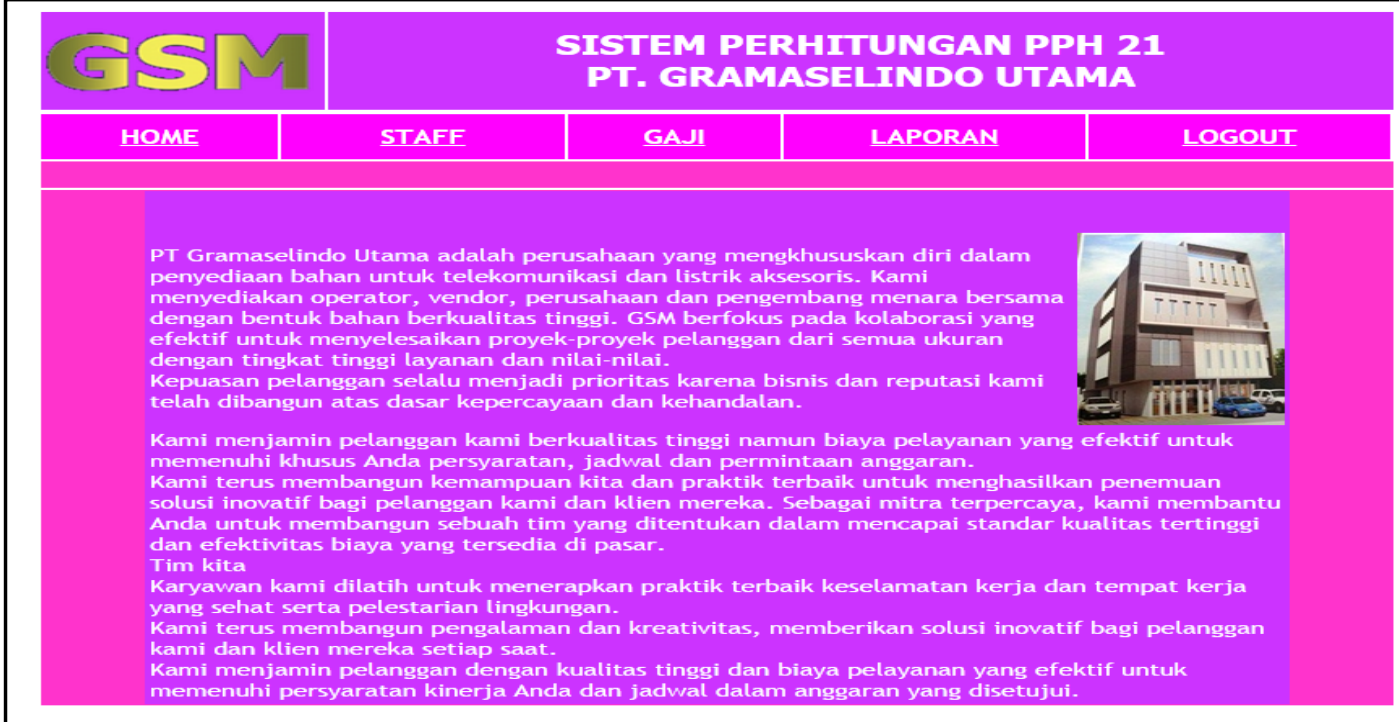

Gambar 3. Menampilkan Home; informasi tentang Perusahaan

Gambar 3 diatas merupakan tampilan website yang dibuat untuk PT.Gramaselindo Utama yang ada pada tampilan awalnya, yaitu: Home. Penjelasan didalamnya mengenai PT.Gramaselindo Utama yang merupakan perusahaan penyedia bahan untuk telekomunikasi dan listrik aksesoris. Didalamnya juga dijelaskan mengenai jaminan kepada pelanggan bahwa bahan-bahannya berkualitas tinggi dengan biaya pelayanan yang efektif sesuai anggaran.

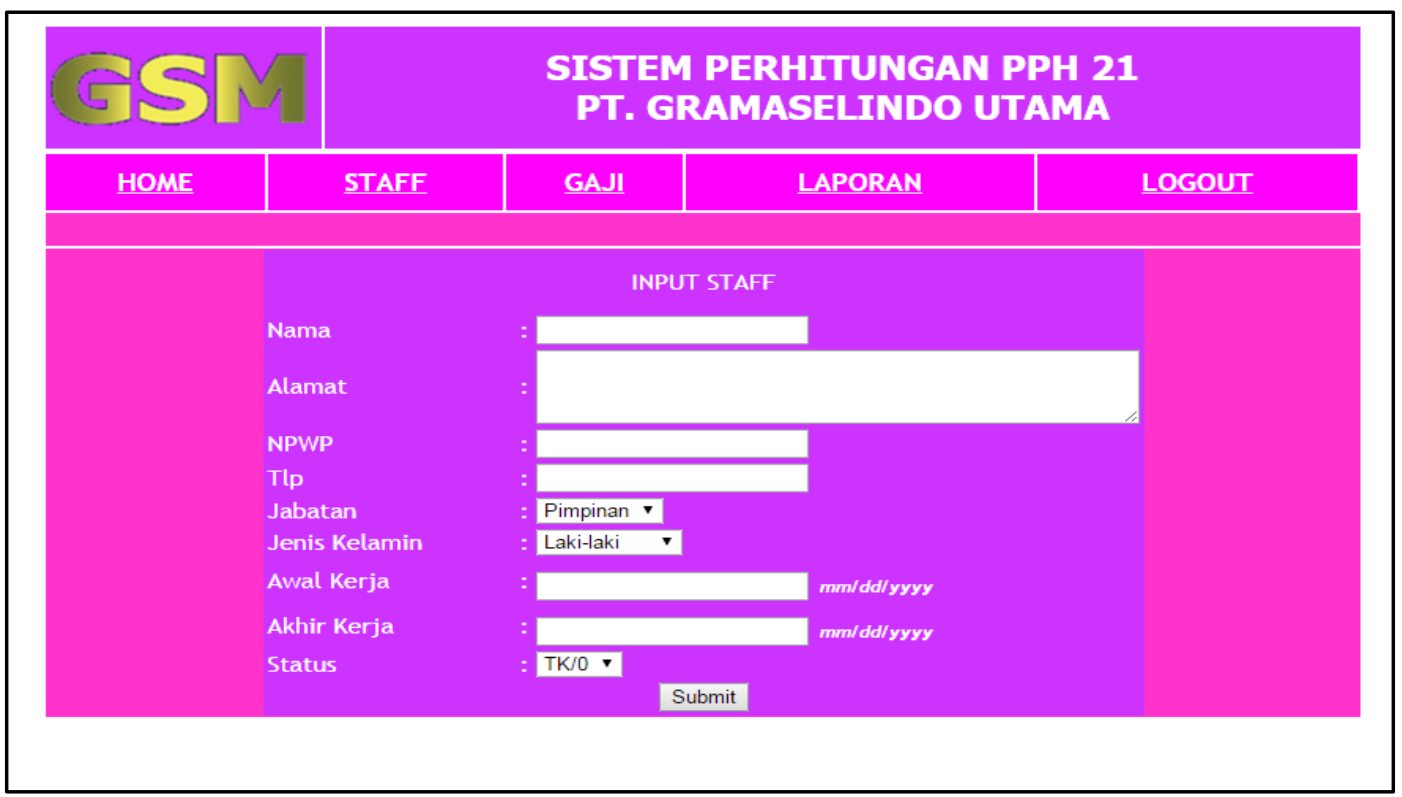

Gambar 4. Menampilkan Input Staff; yang dapat diisi sesuai Data Pribadi Karyawan

Gambar 4 diatas menampilkan Menu Input Staff yang berisi kolom Nama, Alamat, NPWP, Telephone, Jabatan, Jenis Kelamin, Awal Kerja, Akhir Kerja dan Status yang sesuai dengan Data Pribadi masing-masing Karyawan. 


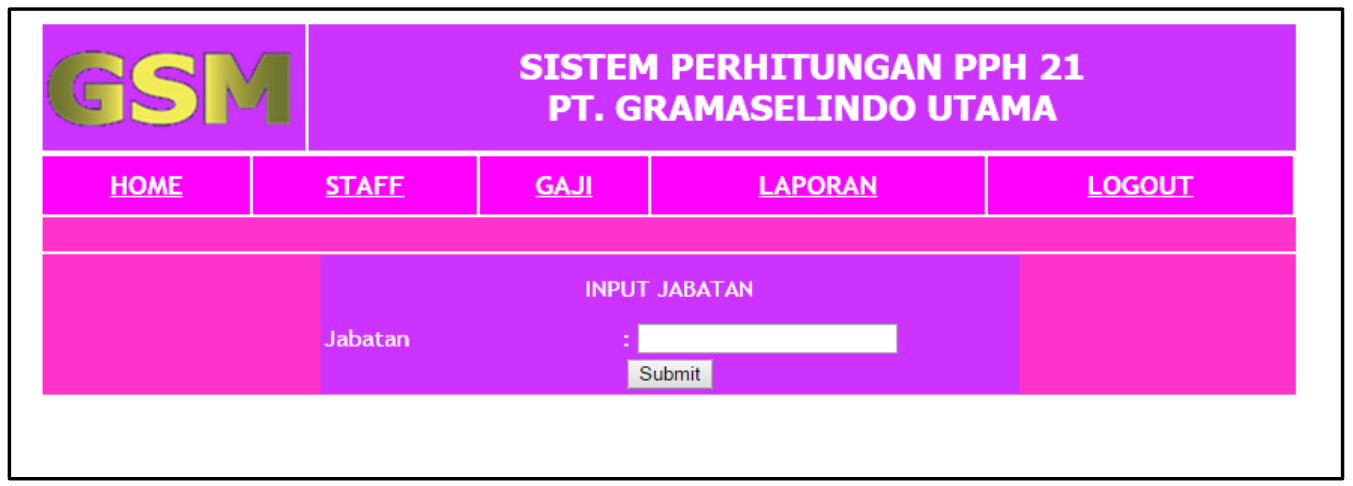

Gambar 5. Menampilkan Input Jabatan

Gambar 5 diatas merupakan Menu Input Jabatan yang khusus menampilkan kolom Jabatan dan tombol Submit. Ini akan berkaitan dengan penggajian dan perhitungan pajak penghasilan (Pph) pasal 21 yang disesuaikan dengan jabatan masing-masing karyawan.

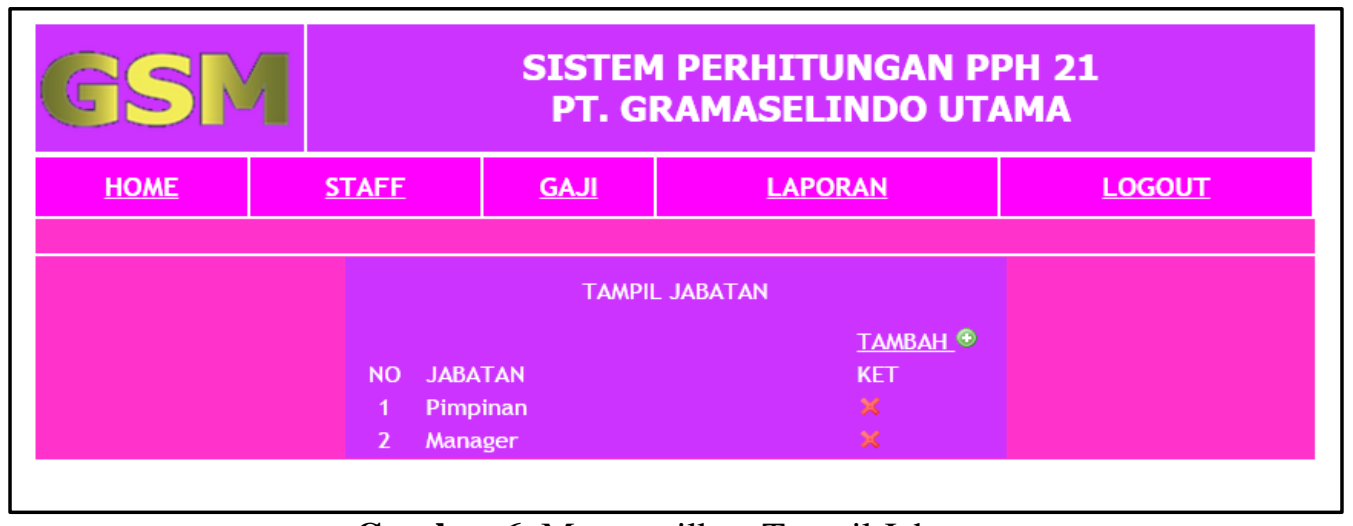

Gambar 6. Menampilkan Tampil Jabatan

Gambar 6 diatas merupakan Menu Tampil Jabatan, yang menampilkan karyawan dengan jabatannya dan keterangan tambahan lainnya.

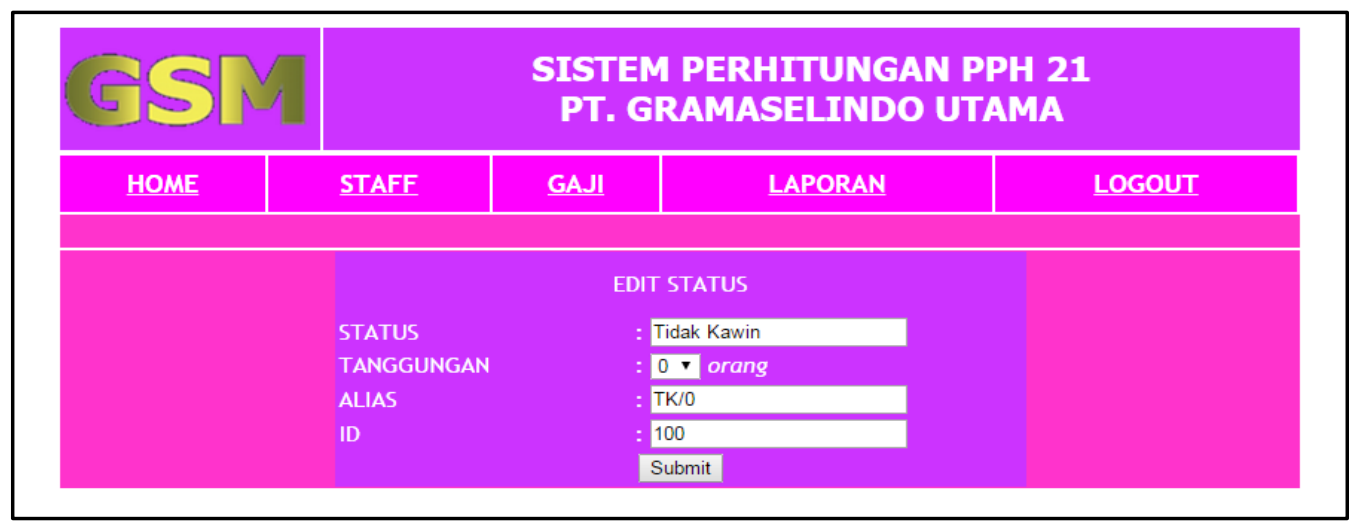

Gambar 7. Menampilkan Edit Status

Gambar 7 diatas merupakan Menu Edit Status yang berisi kolom Status karyawan, berapa jumlah tanggungannya, Alias atau kode status dan nomor ID statusnya, yang gunanya agar dapat diketahui dengan jelas Status masing-masing karyawan PT.Gramaselindo Utama saat ini. 


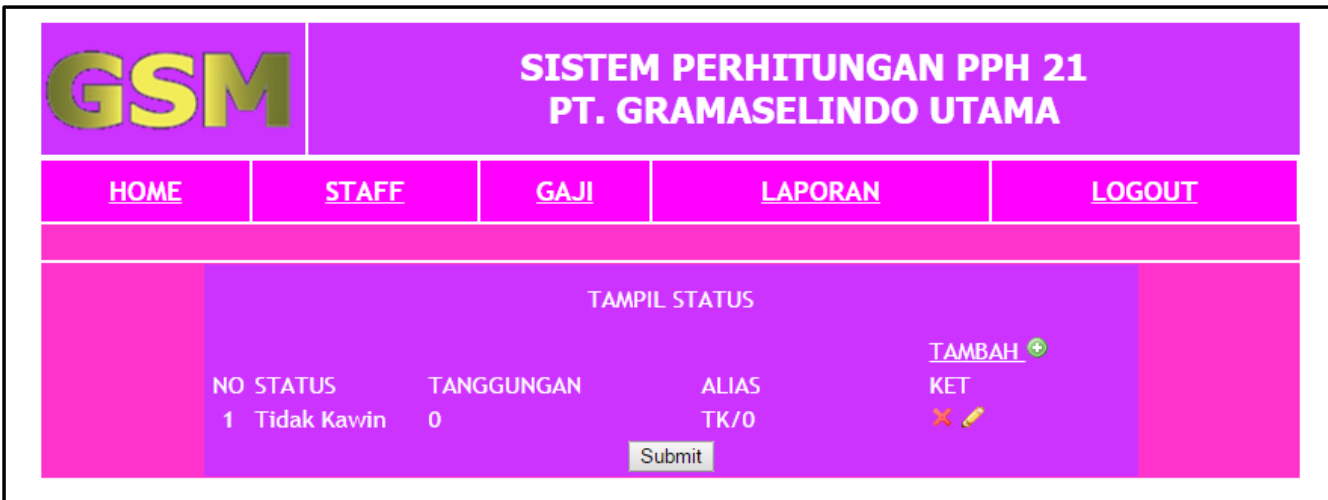

Gambar 8. Menampilkan Tampil Status

Gambar 8 Menampilkan Menu Tampil Status yang merupakan lanjutan dari Edit Status. Didalamnya menampilkan nomor status, jumlah tanggungan, alias dan keterangan tambahan.

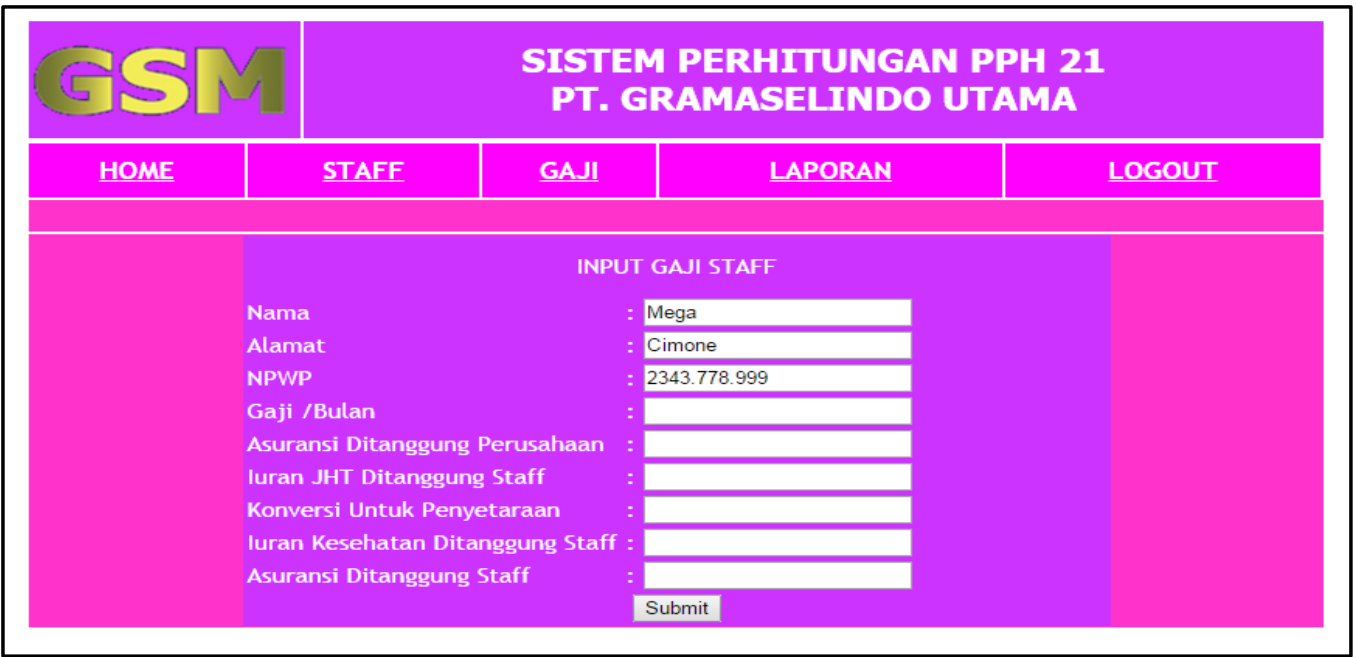

Gambar 9. Menampilkan Input Gaji Staff; yang dapat diisi sesuai dengan Gaji setiap Staff

Gambar 9 menampilkan menu Input Gaji Staff yang berisi kolom Nama, Alamat, NPWP, Gaji perbulan, Asuransi yang ditanggung oleh Perusahaan, Iuran JHT yang ditanggung Staff, kolom keterangan Konversi untuk penyetaraan, Kolom Iuran kesehatan yang ditanggung staff dan Asuransi yang ditanggung Staff.

\section{Kesimpulan}

Sistem informasi Penggajian dan perhitungan Pajak Penghasilan (PPh) khusus pasal 21 saat ini pada PT.Gramaselindo Utama masih dilakukan secara manual dan banyak ditemukan salah perhitungan karena Human Error. Hal ini merugikan karyawan dan juga perusahaan. Selain itu proses pengolahan Penggajian dan perhitungan Pajak Penghasilan (PPh) pasal 21 pada PT.Gramaselindo Utama saat ini juga belum berjalan secara efektif dan efisien karena belum adanya dukungan aplikasi berbasis komputer yang dapat memudahkan pekerjaan HRD dan Accounting Staff. Untuk laporan penggajian dan perhitungan Pajak Penghasilan (PPh) pasal 21 pada PT.Gramaselindo Utama yang berjalan selama ini belum dapat menghasilkan laporan yang cepat dan akurat karena masih terkendala teknologi. 
5. Saran

Disarankan untuk PT.Gramaselindo Utama agar dapat menggunakan aplikasi Website Sistem informasi Penggajian dan perhitungan Pajak Penghasilan (PPh) khusus pasal 21 yang telah dibuat ini sebagai aplikasi kerja sehari-hari, karena dapat membantu memudahkan pekerjaan HRD dan Accounting staff serta karyawan yang membutuhkan informasi penggajian dan pajak penghasilan $(\mathrm{PPh})$ pribadinya. Disarankan untuk PT.Gramaselindo Utama agar dapat memelihara dan mengembangkan Website ini agar menjadi sempurna dan dapat terus digunakan untuk kepentingan bersama.

\section{Daftar Pustaka}

[1] Djp pajak.go.id, "Pph Pasal 21/26", tanggal akses: Selasa, 28 Juli 2020, https://www.pajak.go.id/id/pph-pasal-2126.

[2] Maulani,Giandari. , Sugeng Widada, Nabila Geysaka Amir. 2020. "Media Sistem Informasi Video Profile SMA Permata Insani menggunakan Adobe Creative Cloud". SENSI Journal. Vol.6 No.1 Februari 2020. Tangerang: Universitas Raharja. ISSN: 26555298.

[3] Pramesti,Tri Jata Ayu. 2017. "Struktur dan Skala Upah". Tanggal akses: Jumat, 24 Juli 2020. https://www.hukumonline.com/klinik/detail/ulasan/cl6087/struktur-dan-skalaupah/.

[4] Widyana,Sofie. 2020. "Pengupahan dalam undang-undang ketenagakerjaan". Tanggal akses: Selasa, 28 Juli 2020. http://www.hukumtenagakerja.com/pengupahan/pengupahandalam- undang-undang-ketenagakerjaan/.

[5] djp pajak.go.id, "Pengetahuan Dasar Perpajakan", tanggal akses: Selasa, 28 Juli 2020, https://www.pajak.go.id/index-belajar-pajak.

[6] Kemenkeu. 2020. "Undang-undang Republik Indonesia Nomor.36 tahun 2008 tentang Perubahan keempat atas Undang-undang Nomor.7 tahun 1983 tentang Pajak Penghasilan, $\begin{array}{llll}\text { tanggal akses: } & \text { Selasa, } & 2020 \text {, }\end{array}$ https://jdih.kemenkeu.go.id/fulltext/2008/36tahun2008uu.html

[7] djp pajak.go.id, "Pemotongan pajak penghasilan Pasal 4 ayat (2)", tanggal akses: Selasa, 28 Juli 2020, https://www.pajak.go.id/id/pemotongan-pajak-penghasilan-pasal-4-ayat-20

[8] N Sora, "Pengertian Karyawan dan Jenisnya secara umum", tanggal akses: Jumat, 24 Juli 2020, http://www.pengertianku.net/2017/01/pengertian-karyawan-dan-jenisnya-secaraumum.html

[9] Maimunah., Dian Anggraeni, Miftahul Baihaqi Annazili. 2020. "Perancangan Sistem Informasi Desain Perpustakaan berbasis Web pada SMKN 3 Kota Tangerang". SENSI Journal. Vol.6 No.1 Februari 2020. Tangerang: Universitas Raharja. ISSN: 2655-5298.

[10] Hasanah, H. (2017). Teknik-teknik observasi (sebuah alternatif metode pengumpulan data kualitatif ilmu-ilmu sosial). At-Taqaddum, 8(1), 21-46. 
[11] Syaputri, W., Septianasari, L., \& Abqoriyyah, F. H. (2020). Tantangan Dalam Meningkatkan Kemampuan Berbicara Mahasiswa Dengan Metode Pembelajaran Wawancara. Jurnal Educatio FKIP UNMA, 6(1), 90-97.

[12] Tahmidaten, L., \& Krismanto, W. (2020). Permasalahan Budaya Membaca di Indonesia (Studi Pustaka Tentang Problematika \& Solusinya). Scholaria: Jurnal Pendidikan Dan Kebudayaan, 10(1), 22-33.

[13] Chrismastianto, I. A. W. (2017). Analisis SWOT implementasi teknologi finansial terhadap kualitas layanan perbankan di Indonesia. Jurnal Ekonomi dan Bisnis, 20(1), 134-136.

[14] Wahono, Romi Satrio, "Literature Review: Pengantar dan Metode", tanggal akses: Kamis, 30 Juli 2020, https://romisatriawahono.net/2016/05/07/literature-reviewpengantar-dan-metode/

[15] Isnaini, Syaiful Amarullah.,"Aplikasi Perhitungan Pajak Penghasilan Pasal 21 dan SSP Multi Function Berbasis Website (Studi Kasus : CV.Buana Mitra Consulting)". Skripsi. Universitas Islam Negeri (UIN) Syarif Hidayatullah Jakarta, tanggal akses: Kamis, 30 Juli http://repository.uinjkt.ac.id/dspace/bitstream/123456789/3677/1/syaiful\%20Amarullah\% 20Isnaini-FST.pdf

[16] Panjaitan,Butet Uli Artha.,"Evaluasi Perhitungan Pajak Penghasilan Pasal 21 (Studi Kasus pada PT.X)". Skripsi. Universitas Sanata Dharma Yogyakarta, tanggal akses: $\begin{array}{llll}\text { Kamis } & 30 & \text { Juli }\end{array}$ http://www.library.usd.ac.id/Data\%20PDF/F.\%20Ekonomi/Akuntansi/052114116_full.pd f.

[17] Maghfirah, Hera Bugis Indina., "Analisis Perencanaan Pajak Penghasilan (PPh) Pasal 21 Pegawai Tetap pada PT.Semen Tonasa”. Skripsi. Universitas Hasanudin Makassar.,tanggal akses: $\quad$ Kamis, $30 \quad$ Juli 2020. http://repository.unhas.ac.id/handle/123456789/1817. 